\title{
Sistem Pengukuran Mutu Buah Mangga Berdasarkan Kematangan, Ukuran dan Area Bercak Menggunakan Fuzzy Inference System
}

\author{
Saiful Nur Budiman ${ }^{1}$, Handayani Tjandrasa ${ }^{2}$ \\ Program Studi Teknik Informatika, Fakultas Teknologi Informasi, \\ Institut Teknologi Sepuluh Nopember \\ Email: sync.saifulnb@gmail.com ${ }^{1}$, handatj@its.ac.id ${ }^{2}$
}

\begin{abstract}
ABSTRAK
Grading mangga secara konvensional menggunakan tenaga manusia memerlukan waktu lama dan hasil yang tidak maksimal. Parameter yang digunakan dalam proses grading adalah tingkat kematangan dan kualitas suatu mangga. Tingkat kematangan sebuah mangga ditentukan oleh perubahan warna, sedangkan untuk kualitas ditentukan oleh ukuran dan rasio bercak. Pada penelitian ini FIS (Fuzzy Inference system) Mamdani digunakan untuk mendapatkan hasil grading yang lebih baik berdasarkan parameter warna, ukuran, dan bercak suatu mangga. Conveyer belt digunakan untuk mengangkut mangga sehingga proses grading lebih cepat. Akibatnya, citra mangga mengalami motion blur. Hasil penelitian menunjukkan bahwa pada kondisi diam diperoleh akurasi sebesar 77\%. Sementara pada kondisi bergerak akurasinya semakin menurun.
\end{abstract}

Kata Kunci: Grading Mangga, Motion Blur, Fuzzy Inference System Mamdani

\section{ABSTRACT}

Conventionally grading of mango by manpower spent much more time and the results were not optimal. Parameters used in the grading process were ripeness and quality of a mango. The level of mango ripeness was determined by color change, while the quality was determined by the size and the ratio of spotting. In this research, FIS Mamdani was used for providing better grading based on colour, size, and spotting of a mango. Conveyer belt was used to transport mango so the grading process was faster. As a result, the mango image experienced motion blur. As a result, at stopping position the accuracy was as much as $77 \%$. Meanwhile, the accuracy was tend to decrease at moving condition.

Keywords: Grading Mangoes, Motion Blur, Fuzzy Inference System Mamdani

\section{Pendahuluan}

Buah mangga (Mangifera Indica)merupakan buah musiman yang banyak ditanam di Indonesia.Proses grading dilakukan untuk memilih mangga berkualitas untuk di distributorkan ke konsumen. Secara konvensional grading masih menggunakan tenaga manusia sehingga hasilnya tidak relevan antar individu. Proses grading menjadi tidak efisien jika buah mangga yang dipanen terlalu banyak dengan tenaga kerja yang terbatas, akibatnya proses grading menjadi lama dan sebagian mangga ditimbun di gudang sementara waktu. Penimbunan yang memakan waktu tersebut membuat mangga menjadi rusak dan busuk.

Salah satu parameter yang digunakan untuk proses grading adalah tingkat kematangan buah.Dikembangkan sebuah alat berbasis sensor(Electronic Nose) oleh Brezmesyang mampu mengetahui kematangan buah berdasarkan aroma yang dikeluarkannya [1]. Principal Component Analysis (PCA) digunakan untuk mengurangi dimensi output dari multiple sensor. Indikator kualitas buah didasarkan pada karakteristik fisik dan kimia seperti wujud, tingkat kekerasannya, karakteristik interrnalnya, dan produksi gas [2]. CVV20 merupakan sensor cahaya yang 
digunakan Mansor untuk membedakan kematangan buah mangga[3]. Proses grading dilakukan dengan fuzzy Mamdani dimana input-nya adalah nilai R, G, dan B. Kategori dari output-nya mentah, matang, terlalu matang. Dengan menggunakan bantuan sensor, kematangan suatu buah dapat diidentifikasi namun terbatas pada parameter tertentu. Seperti Electronic Nose yang hanya bisa digunakan untuk parameter aroma saja sedangkan sensor CV-V20 hanya untuk parameter warna saja.

Penelitian terus dikembangkan lebih lanjut untuk mengetahui kematangan buah mangga, salah satunya dengan CVS (Computer Vision System). Zheng menggunakan LS-SVM (Least Square Support Vector Machine) untuk mengklasifikasikan kematangan buah mangga berdasarkan fractal analysisdan parameter CIELab [4]. Pada tahun yang sama, Savakar melakukan identifikasi dan klasifikasi berbagai macam buah seperti apel, sawo, mangga, jeruk dan lemon menggunakan 18 fitur warna dan 27 fitur tekstur [5]. Pada tahap pelatihan dan pengenalannya menggunakan BPNN (Back Propagation Neural Network). Vyas membuat algoritma sederhana untuk mempermudah proses grading mangga dengan basic rules dari tiga parameter input yakni warna, ukuran dan bercak [6]. Dari penilitian [4], [5] dan [6] tersebut terdapat kesamaan dimana citra mangga pada keadaan statis (citra dalam kondisi diam), sehingga citranya tidak mengalami derau. Pada kenyataanya untuk proses grading supaya cepat dan efektif harus diletakkan padaconveyer belt. Dengan meletakkan mangga di conveyer belt, citra yang diambil akan mengalami motion blur.Nandi membuat mesin yang mampu melakukan sorting mangga berdasarkan karakteristik warna citra[7]. Kondisi citra mangga yang mengalami motion blur direstorasi denganWiener filter. ROI yang diperoleh kemudian dibagi menjadi tiga bagian yakni apex, equator, stalk.
Berdasarkan tiga bagian tersebut dilakukan ekstraksi fitur. Proses pelatihan dan pengenalannya menggunakan SVM (Support Vector Machine). Pada penelitian yang berikutnya, Nandi mengembangkan mesin gradingmangga dengan menambahkan parameter kualitas[8]. Untuk mesin grading, proses yang sebelumnya menggunakan SVM diganti dengan GMM (Gaussian Mixture Model).Tingkat kematangan dan kualitas menjadi input untuk menentukan grade dari mangga dengan metode FIS Mamdani.

Berdasarkan dari latar belakang penelitian yang telah dipaparkan sebelumnya, maka diusulkan strategi baru untuk mengukur mutu buah mangga berdasarkan karakterisik kematangan, ukuran dan area bercak menggunakan FIS Mamdani denganinput citra yang mengalami deraumotionblur.Parameter warna yang digunakan adalah mean red dan mean green pada ROI yang telah di crop. Parameter ukuran diperoleh dengan cara menghitung keseluruhan piksel ROI. Parameter bercak ditentukan dengan cara membandingkan jumlah bercak dengan jumlah piksel pada ROI. Mangga yang digunakan pada penelitian ini adalah jenis mangga apel.

\section{Kajian Pustaka}

\subsection{Restorasi Citra pada Motion Blur}

Restorasi citra merupakan bagian penting dalam pengolahan citra untuk memperbaiki citra yang sebelumnya mengalamai derau ke bentuk aslinya atau menyerupai citra aslinya. Restorasi citra berbeda dengan enchancement, dimana pada restorasi citra dianggap sebagai model citra terdistorsi yang telah diketahui permasalahannya atau dapat diprediksi penyebab kesalahannya. Sedangkan enhancement merupakan perbaikan citra yang bertujuan untuk meningkatkan kualitas tampilan citra untuk pandangan manusia atau untuk mengkonversi suatu citra agar memiliki format yang lebih baik sehingga citra tersebut menjadi mudah 
diolah oleh komputer [9]. Teknik dari restorasi citra meliputi operasi neighbourhood dan juga penggunaan proses pada domain frekuensi. Model dari citra yang mengalami derau ditunjukkan pada Gambar1[10].

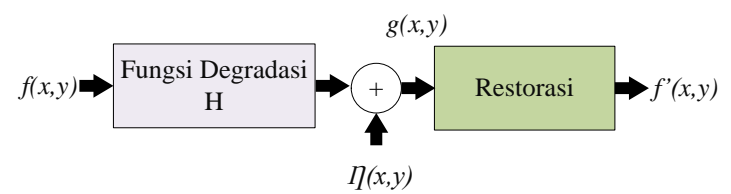

Gambar 1. Model Citra Derau

$g(x, y)=f(x, y) \otimes h(x, y)$

$g(x, y)=f(x, y) \otimes h(x, y)+\eta(x, y)$

$\hat{F}(u, v)=\frac{G(u, v)}{H(u, v)}$

$\hat{F}(u, v)=\frac{G(u, v)}{H(u, v)}-\frac{N(u, v)}{H(u, v)}$

$e^{2}=E(f-\hat{f})^{2}$

$\hat{F}(u, v)=$

$\left[\frac{1}{H(u, v)} x \frac{|H(u, v)|^{2}}{|H(u, v)|^{2}+\frac{S_{\eta}(u, v)}{S_{f}(u, v)}}\right] G(u, v)$

$\hat{F}(u, v)=\left[\frac{1}{H(u, v)} x \frac{|H(u, v)|^{2}}{|H(u, v)|^{2}+k}\right]$

Persamaan (1) menyatakan bahwa citra derau $g(x, y)$ merupakan proses dari operasi spasial antara citra asli $f(x, y)$ dengan $h(x, y)$ yang merupakan PSF (Point Spread Function). Pada persamaan (2) derau terjadi jika ada tambahan noise $(x, y)$. Dari persamaan tersebut, yang menjadi faktor citra mengalami degradasi adalah blur dan noise. Pada proses restorasi untuk memperoleh kembali citra seperti sebelum mengalamai derau maka perlu dilakukan inversefilter. Berdasarkan persamaan (1) dan (2) maka invers filter dinyatakan dengan bentuk transformasi Fourier pada persamaan (3) dan (4). Dari persamaan (4), untuk mendapatkan citra asli tidak hanya melibatkan permasalahn pembagian dengan filterH tetapi juga permasalahan untuk mengatasi derau. Kenyataanya, derau dapat membuat invers filter tidak berguna jika derau mendominasi keluaran. Untuk mengurangi sensitivitas derau pada invers filter, berbagai pendekatan untuk melakukan restorasi citra telah dilakukan. Secara umum, pendekatan tersebut dinamakan sebagai filterleast square. Salah satu filter tersebut adalahWiener filter. Wiener filter merupakan metode untuk merestorasi citra berdasarkan Mean SquareError(MSE) yaitu dengan cara meminimumkan error restorasi antara citra restorasi dengan citra asli yang ditunjukkan pada persaman (5). Filter ini efektif untuk karakteristik frekuensi citra dan derau aditif yang diketahui. Persamaan dari Wiener filter ditunjukkan pada persamaan (6). $S_{\eta(u, v)}$ merupakan derau power spectrum, sedangkan $S_{f(u, v)}$ adalah power spectrum dari citra yang belum terderau. Apabila derau nol, maka Wiener filter menjadi invers filter untuk white noise, power spectrum derau konstan yang ditunjukkan pada persamaan (7).

\subsection{Fuzzy Mamdani}

Logika boolean klasik hanya menghasilkan 0 atau 1 , sedangkan pada fuzzy menggantikan kebenaran boolean dengan tingkat kebenaran. Awal mula fuzzy diperkenalkan oleh Zadeh dimana dalam teorinya obyek-obyek dari himpunan fuzzy yang memiliki batasan yang tidak presisi dan keanggotaan dalam himpunan fuzzy dan bukan dalam bentuk logika benar (true) atau salah (false). Secara umum, sistem fuzzy cocok untuk penalaran pendekatan terutama untuk sistem yang menangani masalah yang sulit didefinisikan dengan menggunakan model matematis[11].

Himpunan fuzzy adalah sekumpulan obyek $x$ dimana masing-masing obyek memiliki nilai keanggotaan (membership function) $\mu$ atau disebut dengan nilai kebenaran. Fungsi Keanggotaan berupa suatu kurva yang menunjukkan titik-titik input data ke dalam nilai keanggotaannya atau derajat keanggotaannya yang memiliki interval antara 0 sampai 1 . Basis aturan berupa sekumpulan aturan yang terdapat 


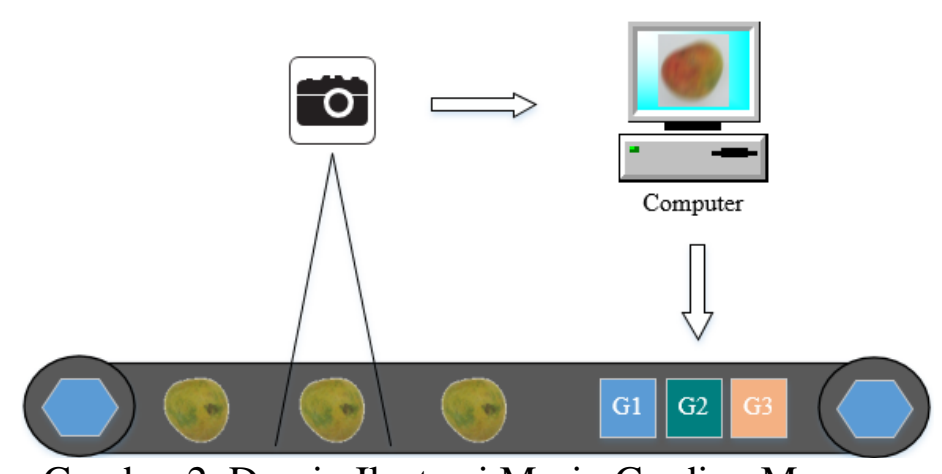

Gambar 2. Desain Ilustrasi Mesin Grading Mangga

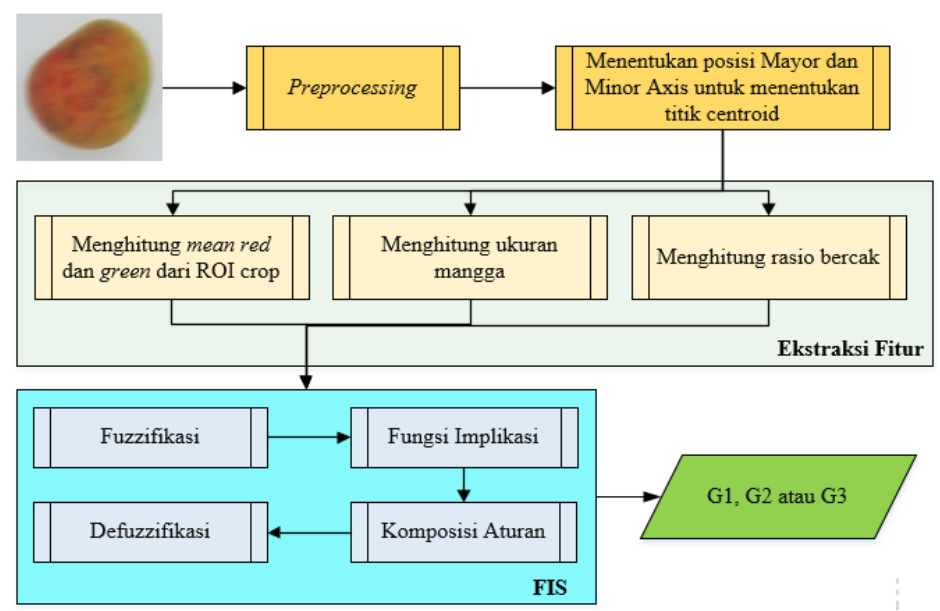

Gambar 3. Desain Algoritma yang Diusulkan

pada sistem fuzzy. Dengan kata lain, basis aturan if-thenfuzzy digunakan untuk menangkap maksud yang tidak jelas dari pemikiran sesuai dengan kemampuan manusia yang mampu membuat keputusan di lingkungan yang tidak pasti dan tidak jelas. Sistem inferensi merupakan sistem pengambilan keputusan yang didasarkan pada teori fuzzy, aturan fuzzyif-then dan logika fuzzy. Metode fuzzy Mamdani sering disebut juga dengan metode Max-Min. Metode ini diperkenalkan oleh Ebrahim Mamdani pada tahun 1975. Proses untuk mendapatkan output melalui 4 tahapan yakni pembentukan himpunan fuzzy, implikasi, komposisi aturan, dan defuzzifikasi.

\section{Metodologi}

\subsection{Perancangan Algoritma}

Rancangan desain sistem yang ingin diterapakan ditunjukan pada Gambar 2.
Dimana mangga diletakan pada conveyer belt dengan kecepatan tertentu. Kamera akan mengambil gambar mangga kemudian melakukan proses perhitungan untuk melakukan grading berdasarkan tingkat warna, ukuran, dan bercak. Setelah perhitungan selesai maka mangga masuk kelubang penampungan sesuai dengan hasil grading yakni jelek, biasa, super.

Adanya keterbatasan dalam membuat mesin grading, maka pada penelitian ini hanya membahas proses grading-nya bukan cara membuat mesinya. Pada penelitian ini citra mangga di-capture dalam keadaan normal dimana tidak terjadi kontak pencahayaan langsung dari matahari. Hasil dari citra mangga tersebut kemudian diberi deraumotionblur seolah seperti yang terjadi ketika citra mangga tersebut diambil melalui conveyer belt yang bergerak. Secara keseluruhan proses dalam penelitian ini ditunjukkan pada Gambar 3. 


\subsection{Preprocessing}

Dilakukan prosesdebluringdengan Wiener filter pada citra mangga yang mengalami motionblur. Parameter PSF (Point Spread Function) pada Wiener filter diperoleh dari parameter motionblur yang sebelumnya ditambahkan pada citra mangga di awal. Hasil dari Wiener filter ini masih terdapat derau, sehingga diperlukan metode penghilang derau. Untuk menghilangkan derau tersebut diusulkan menggunakan Median filter. Langkah berikutnya, citra mangga dirubah ke grayscale lalu dilakukan segmentasi untuk memisahkan obyek dengan background menggunakan Otsu thresholding. Dalam kondisi yang nyata, tentunya mangga tidak selalu diletakkan dalam posisi yang selalu benar. Bisa saja mangga diletakkan miring atau terbalik, sebab itu dilakukan proses rotasi pada citra ROI secara vertikal dimana bagian pangkal mangga harus berada di atas. Secara alami warna kematangan mangga dimulai dari pangkal sampai ke ujung. Inilah yang menjadi alasan mengapa harus diputar dan dilakukan proyeksi untuk menghitung mean red dan green secara benar.

\subsection{Ekstraksi Fitur}

Tahap berikutnya adalah menghitung mean red dan mean green pada bagian ROI cropsebagai parameter input pertama untuk fuzzy. Sebelum melakukan croping ROI, terlebih dahulu harus mengetahui titik centroid. Dimana centroid merupakan titik tengah atau titik potong antara minor dan mayor axis.Titik centroid ini kemudian diperlebar $30 \%$ dan diperpanjang $80 \%$ sehingga membentuk suatu garis. Setelah garis centroid terbentuk, dilakukan proses croping. Dari ROI crop inilah nilai mean red dan mean green bisa dihitung.Parameter input kedua adalah ukuran dari ROI mangga dengan cara mengubah ROI mangga ke citra biner. Dengan menghitung jumlah piksel putihnya maka akan diperoleh ukuran dari mangga.
Parameter input yang ketiga berupa rasio bercak mangga.Untuk mencari rasio dari bercak ditunjukkan pada persamaan 8 .

Rasio bercak $=\frac{\text { jumla } h \text { bercak }}{\text { Jumla h piksel di ROI }}$

Akan menjadi masalah jika bercak tersebut merupakan pangkal atau bercak asli mangga seperti yang ditunjukkan pada Gambar 4 (a) ROI mangga, 4 (b) bagian yang menunjukkan bercak. Citra mangga dirubah ke grayscale lalu dicari levelnya menggunakan Otsu dan dirubah ke citra biner. Dari citra biner ini akan tampak warna hitam yang menandakan bercak. Untuk membedakan bercak asli dengan bercak pangkal adalah dengan melakukan masking citra biner ini dengan citra yang sudah ada garis centroid-nya. Jika bercak berada pada ujung atas dari garis centroid maka bercak tersebut dianggap sebagai bercak pangkal mangga, sehingga tidak dihitung sebagai bercak sedangkan yang lainya dianggap sebagai bercak.

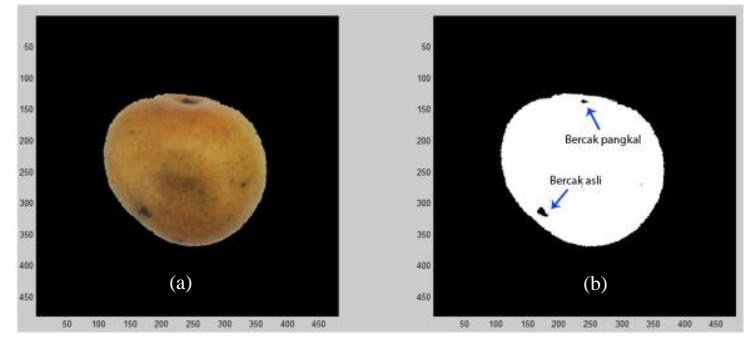

Gambar 4. ROI Mangga (a), Perbedaan Bercak Asli dengan Bercak Pangkal (b)

\subsection{Grading Dengan Fuzzy Mamdani}

Berdasarkan mean red, mean green, ukuran dan rasio bercak maka proses grading dilakukan dengan menggunakan FIS Mamdani. Pada Tabel 1 ditunjukkan semesta pembicara untuk membangun FIS. Variabel $\mathrm{Mr}$ yang merupakan rerata nilai red yang dikategorikan menjadi tiga derajat keanggotaan yakni sedikit, sedang dan banyak. Semakin sedikit maka mangga tersebut mentah, begitu juga sebaliknya.Representasi untuk mangga 
dengan nilai yang sedikit digambarkan dengan bentuk linear turun. Sedangkan untuk representasi sedang menggunakan bentuk kurva segitia. Fungsi keanggotaan banyak digambarkan dalam bentuk linear naik. Detail dari nilai fungsi keanggotaan mean red ditunjukkan pada persamaan 9 .

Untuk variabel $M g$ sama halnya dengan variabel $M r$ bedanya, ini merupakan rearata green. Pada rerata green derajat keanggotaanya dikategorikan juga menjadi tiga yakni sedikit, sedang dan banyak. Semakin sedikit nilainya maka mangga matang. Bentuk linear turun digunakan untuk merepresentasikan sedikit, linear naik sebagai representasi banyak, sedangkan representasi untuk sedang berupa kurva segitia. Untuk fungsi keanggotaan mean green ditunjukkan pada persamaan 10 .

Tabel 1. Semesta Pembicara Grading Mangga Apel

\begin{tabular}{|c|c|c|c|c|}
\hline$\underset{i}{\text { Fungs }}$ & Var & $\begin{array}{c}\text { Notas } \\
\mathbf{i}\end{array}$ & $\begin{array}{c}\text { Semesta } \\
\text { Pembicar } \\
\text { a }\end{array}$ & $\begin{array}{c}\text { Keteranga } \\
\mathbf{n}\end{array}$ \\
\hline \multirow{4}{*}{ Input } & $\mathrm{Sz}$ & w1 & [0-1] & $\begin{array}{c}\text { Ukuran } \\
\text { mangga }\end{array}$ \\
\hline & $\mathrm{Rb}$ & w2 & {$[0-1]$} & $\begin{array}{l}\text { Rasio } \\
\text { bercak }\end{array}$ \\
\hline & $\mathrm{Mr}$ & w3 & {$[0-1]$} & Mean Red \\
\hline & $\mathrm{Mg}$ & w4 & {$[0-1]$} & $\begin{array}{l}\text { Mean } \\
\text { Green }\end{array}$ \\
\hline$\underset{t}{\text { Outpu }}$ & Gr & $\mathrm{z}$ & [0-1] & $\begin{array}{c}\text { Grade } \\
\text { mangga }\end{array}$ \\
\hline
\end{tabular}

$$
\begin{aligned}
& \mu_{\text {sedikit }}\left(w_{1}\right)=\left\{\begin{array}{c}
1, w_{1} \leq 0 \\
\frac{0.4185-w_{1}}{0.4185-0.0465}, 0.0465 \leq w_{1} \leq 0.4185 \\
0, w_{1} \geq 0.4185
\end{array}\right. \\
& \mu_{\text {sedang }}\left(w_{1}\right)=\left\{\begin{aligned}
0, & w_{1} \leq 0.365 \text { atau } w_{1} \geq 0.95 \\
\frac{w_{1}-0.365}{0.657-0.365}, & 0.365 \leq w_{1} \leq 0.657 \\
\frac{0.95-w_{1}}{0.95-0.657}, & 0.657 \leq w_{1} \leq 0.95 \\
0, & w_{1} \leq 0.685
\end{aligned}\right. \\
& \mu_{\text {banyak }}\left(w_{1}\right)=\left\{\begin{aligned}
\frac{w_{1}-0.685}{0.965-0.685}, & 0.685 \leq w_{1} \leq 0.965 \\
1, & w_{1} \geq 0.965
\end{aligned}\right. \\
& \mu_{\text {sedikit }}\left(w_{2}\right)=\left\{\begin{aligned}
1, & w_{2} \leq 0.0305 \\
\frac{0.2745-w_{2}}{0.2745-00305}, & 0.0305 \leq w_{2} \leq 0.2745 \\
0, & w_{2} \geq 0.2745 \\
0, & w_{2} \leq 0.187 \text { atau } w_{2} \geq 0.667
\end{aligned}\right. \\
& \mu_{\text {sedang }}\left(w_{2}\right)=\left\{\begin{aligned}
\frac{w_{2}-0.187}{0.427-0.187}, & 0.187 \leq w_{2} \leq 0.427 \\
\frac{0.667-w_{2}}{0.667-0.427}, & 0.427 \leq w_{2} \leq 0.667
\end{aligned}\right.
\end{aligned}
$$

$\mu_{\text {banyak }}\left(w_{2}\right)=\left\{\begin{aligned} 0, & w_{2} \leq 0.4645 \\ \frac{w_{2}-0.4645}{0.9405-0.4645}, & 0.4645 \leq w_{2} \leq 0.9405 \\ 1, & w_{2} \geq 0.9405\end{aligned}\right.$

Fungsi keanggotaan variabel $S z$ dibagi menjadi tiga kategori kecil, sedang, besar. Bentuk derajat keanggotaan linear turun untuk representasi ukuran yang kecil dan linear naik untuk representasi ukuran besar. Derajat keanggotaan segitiga untuk ukuran mangga yang sedang. Pada persamaan 11 ditunjukkan fungsi keanggotaanya.

Variabel $R b$ yang merupakan rasio bercak yang dikategorikan menjadi tiga yakni bercaknya kecil, sedang, besar. Representasi linear turun untuk rasio yang sedikit, sedangkan linear naik digunakan untuk merepresntasikan rasio yang memiliki bercak besar. Derajat keanggotaan sedang direpresentasikan dengan bentuk kurva segitia. Untuk Fungsi keanggotaanya ditunjukkan pada persamaan 12 .

$$
\begin{aligned}
& \mu_{\text {kecil }}\left(w_{3}\right)=\left\{\begin{aligned}
1, & w_{3} \leq 0.0485 \\
\frac{0.4365-w_{3}}{0.4365-0.0485}, & 0.0485 \leq w_{3} \leq 0.4365 \\
0, & w_{3} \geq 0 \\
0, & w_{3} \leq 0.305 \text { atau } w_{3} \geq 0.65
\end{aligned}\right. \\
& \mu_{\text {sedang }}\left(w_{3}\right)=\left\{\begin{aligned}
\frac{w_{3}-0.305}{0.4775-0.305}, & 0.305 \leq w_{3} \leq 0.4775 \\
\frac{0.65-w_{3}}{0.65-0.4475}, & 0.4475 \leq w_{3} \leq 0.65 \\
0, & w_{3} \leq 0.505
\end{aligned}\right. \\
& \mu_{\text {besar }}\left(w_{3}\right)=\left\{\begin{aligned}
\frac{w_{3}-0.505}{0.945-0.505}, & 0.505 \leq w_{3} \leq 0.945 \\
1, & w_{3} \geq 0.945
\end{aligned}\right. \\
& \mu_{\text {kecil }}\left(w_{4}\right)=\left\{\begin{aligned}
1, & w_{4} \leq 0.0175 \\
\frac{0.1575-w_{4}}{0.1575-0.0175}, & 0.0175 \leq w_{4} \leq 0.1575 \\
0, & w_{4} \geq 0.1575 \\
0, & w_{4} \leq 0.12 \text { atau } w_{4} \geq 0.505
\end{aligned}\right. \\
& \mu_{\text {sedang }}\left(w_{4}\right)=\left\{\begin{aligned}
\frac{w_{4}-0.12}{0.312-0.12}, & 0.12 \leq w_{4} \leq 0.312 \\
\frac{0.505-w_{4}}{0.505-0.312}, & 0.312 \leq w_{4} \leq 0.505 \\
0, & w_{4} \leq 0.4645
\end{aligned}\right. \\
& \mu_{\text {besar }}\left(w_{4}\right)=\left\{\begin{aligned}
\frac{w_{4}-0.4645}{0.9405-0.4645}, & 0.4645 \leq w_{4} \leq 0.9405 \\
1, & w_{4} \geq 0.9405
\end{aligned}\right.
\end{aligned}
$$

Fungsi keanggotaan untuk variabel output yaitu untuk grading memiliki 3 derajat keanggotaan yakni rendah, sedang dan tinggi. Himpunan keanggotaan untuk himpunan rendah direpresentasikan dengan bentuk linear turun. Untuk keanggotaan himpunan tinggi direpresentasikan dengan bentuk linear naik. Sementara untuk himpunan sedang direpresentasikan dengan bentuk kurva segitiga. Fungsi 
keanggotaanya ditunjukkan pada persamaan 13. Rule yang dibentuk merupakan hasil dari pengamatan data training. Pada Tabel 2 ditunjukkan rule yang menjadi aturan umum yang biasa digunakan. Dari hasil output ini nanti, bisa dikategorikan berdasarkan grade-nya.

$$
\begin{aligned}
& \mu_{\text {renda } h}(z)=\left\{\begin{array}{cl}
1, & z \leq 0.04 \\
\frac{0.36-z}{0.36-0.04,}, & 0.04 \leq z \leq 0.36 \\
0, & z \geq 0.36
\end{array}\right. \\
& \mu_{\text {sedang }}(z)=\left\{\begin{array}{cl}
0, & z \leq 0.1 \text { atau } z \geq 0.9 \\
\frac{z-0.1}{0.5-0.1}, & 0.1 \leq z \leq 0.5 \\
\frac{0.9-z}{0.9-0.5}, & 0.5 \leq z \leq 0.9 \\
0, & z \leq 0.64
\end{array}\right. \\
& \mu_{\text {tinggi }}(z)=\left\{\begin{aligned}
\frac{z-0.64}{0.96-0.64}, & 0.64 \leq z \leq 0.96 \\
1, & z \geq 0.96
\end{aligned}\right.
\end{aligned}
$$

Tabel 2. Rule Grading Mangga Apel

\begin{tabular}{llllll}
\hline ID & \multicolumn{5}{c}{ Variabel Input } \\
\cline { 2 - 5 } Rule & Mr & Mg & Sz & Rb & \\
\hline R1 & sedikit & sedikit & kecil & kecil & rendah \\
R2 & sedikit & sedikit & kecil & sedang & rendah \\
R4 & sedikit & sedikit & sedang & kecil & rendah \\
R5 & sedikit & sedikit & sedang & sedang & rendah \\
R25 & sedikit & banyak & besar & kecil & rendah \\
R26 & sedikit & banyak & besar & sedang & rendah \\
R27 & sedikit & banyak & besar & besar & rendah \\
R28 & sedang & sedikit & kecil & kecil & sedang \\
R29 & sedang & sedikit & kecil & sedang & sedang \\
R30 & sedang & sedikit & kecil & besar & rendah \\
R34 & sedang & sedikit & besar & kecil & tinggi \\
R35 & sedang & sedikit & besar & sedang & sedang \\
R43 & sedang & sedang & besar & kecil & tinggi \\
R44 & sedang & sedang & besar & sedang & sedang \\
R61 & banyak & sedikit & besar & kecil & tinggi \\
\hline
\end{tabular}

\subsection{Dataset}

Dataset diambil secara langsung di kebun mangga yang ada daerah Sedati, Sidoarjo. Terdapat empat macam tingkat kematangan yang berbeda yakni mentah, setengah matang, matang dan terlalu matang. Secara berturut ditunjukkan pada Gambar 5. Terdapat 55 citra sebagai dataset dan 22 citra sebagai data uji. Pada Gambar 5 ditunjukkan contoh citra yang digunakan sebagai dataset.

Groundtruth dari mangga dilakukan dengan cara mengelompokkan buah mangga berdasarkan jenis kematangan, ukuran serta bercaknya secara manual. Misalkan saja buah mangga tersebut memiliki tingkat kematangan mentah atau dapat dikatakan nilai mean red lebih sedikit dibandingkan mean green, ukuranya besar serta nilai dari rasio bercaknya sedikit maka akan dikelompokkan menjadi mangga dengan grade yang jelek. Untuk grade yang biasa dapat dilihat dari mangga yang memiliki tingkat kematangan setengah matang atau matang, ukurannya sedang, rasio bercaknya sedang. Apabila mangga tersebut terlalu matang dimana nilai mean red lebih dominan dibanding mean green, ukurannya besar dan rasio bercaknya sedikit maka masuk dalam kategori grade super. 


\section{Analisa Hasil}

\subsection{Hasil Proses Pembentukan ROI}

Pada Gambar 6 (a) merupakan citra yang mengalami derau motion blur. Derau berupa motionblur ini bisa di debluring dengan metode Wiener filter dan hasilnya ditunjukkan pada Gambar 6 (b). Setelah citra mengalami proses debluring, maka tahapan selanjtunya adalah melakukan segmentasi untuk mendapatkan ROI. Langkah awal mengubah citra menjadi biner. Citra biner yang dihasilkan dikalikan secara skalar dengan citra hasil debluring untuk mendapatkan ROI mangga seperti yang ditunjukkan pada gambar 6 (c). Citra ROI, selanjtunya harus dirotasi sedemikian rupa supaya jelas mana bagian ujung dan bagian pangkal dari mangga apel ini. Berbeda dengan kebanyakan mangga lainnya yang biasanya berbentuk lonjong jadi lebih mudah dilakukan rotasi. Citra mangga harus diputar secara benar, sehingga bagian pangkalnya ada di atas dan ujungnya ada dibawah. Dengan menghitung nilai gradient dari citra biner tersebut maka diperoleh berapa derajat citra biner tersebut harus dirotasi yang ditunjukkan pada Gambar 6 (d).
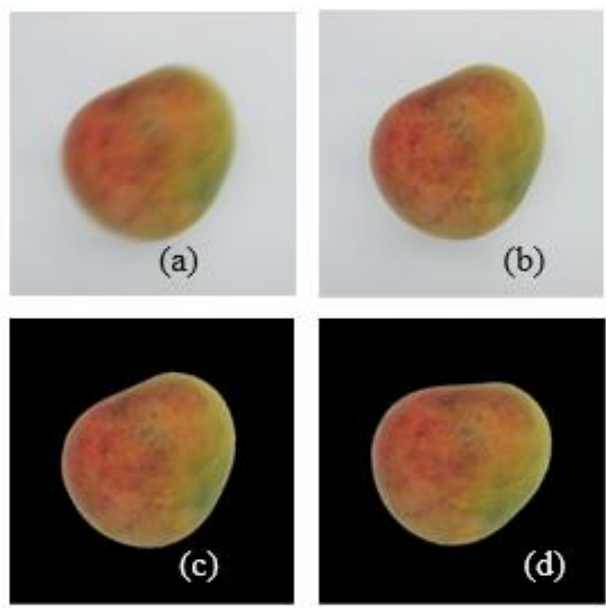

Gambar 6. Pembentukan ROI

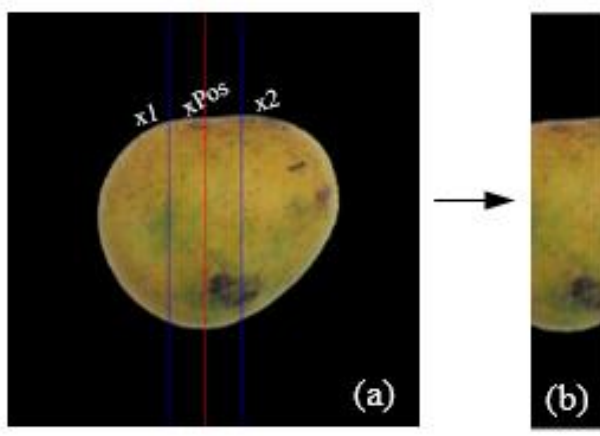

Gambar 7. Pembentukan ROI Crop
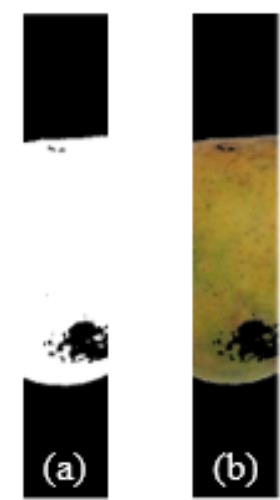

Gambar 8. Citra Crop Mask

\subsection{Hasil Ekstraksi Fitur}

Untuk fitur ukuran mangga diperoleh dari ROI mangga yang diubah ke biner kemudian dihitung jumlah piksel yang berwarna putih sebagai fitur size. Rasio bercak merupakan perbandingan jumlah bercak dengan ukuran dari mangga. Semakin kecil rasio bercak, semakin bagus mangga tersebut. Untuk memperoleh rasio bercak, ROI mangga ditingkatkan kontrasnya agar bercak benar-benar terlihat. Untuk mendapatkan fitur mean red dan mean green diperoleh dengan cara melakukancroping secara vertikal pada bagian tengah mangga. Untuk itu, ROI manggapada Gambar 7(a) diproyeksikan terhadap sumbu $x$ untuk mendapatkan garis tengah dari ROI yang dinamakan xPos. Nilai dari $x P o s$ dikalikan dengan $15 \%$ ke kanan dan kekiri sehingga diperoleh nilai $x 1$ dan $x 2$. Proses croping dimulai dari titik $x 1,0$ sampai $x 2,0$ yang menghasilkan citra cropingpada Gambar7 (b).

Setiap channelpada citra hasil cropingdipertajam kontrasnya supaya 
bercak terlihat lebih jelas. Dari tiap channel dijadikan biner dan disatukan kembali. Hasil dari citra crop biner dijadikan mask untuk mendapatkan citra crop yang sudah tidak ada bercaknya. Hal ini ditunjukkan pada Gambar8 (a) mask dan 8 (b) citra crop hasil masking-nya. Citra hasil masking dipisahkan kembali channelnya, namun yang dipakai hanya channelred dan green saja. Dari setiap channel dihitung nilai mean-nya.

\subsection{Hasil Fuzzy Mamdani}

Data training digunakan untuk membentuk membership function dan rule. Terdapat 55 data training dari citra mangga yang sudah dikelompokkan berdasarkan tingkat kematangannya. Berdasarkan data training ini dilakukan pengujian terhadap target sampai ditemukan nilai akurasi diatas $70 \%$. Jika nilai akurasi kurang dari $70 \%$ maka dilakukan perbaikan secara manual dengan melakukan pergeseran pada membership

function.

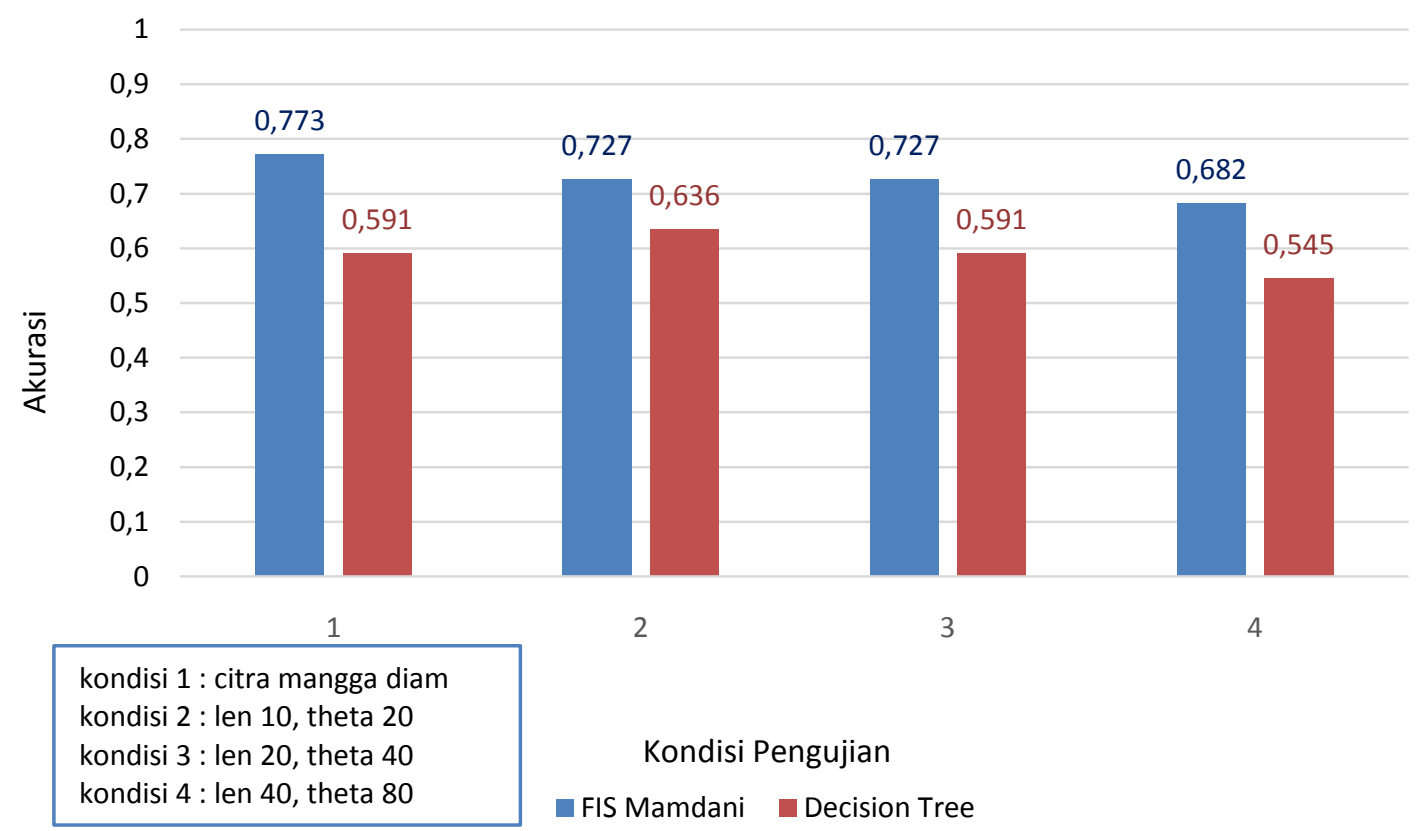

Gambar 9. Grafik Perbandingan Akurasi

Untuk melakukan pengujian dilakukan dengan menguji citra mangga dengan beberapa kondisi. Kondisi 1 adalah citra mangga diam, kondisi 2, 3, 4 adalah citra mangga dengan motion blur yang berbedabeda. Dari hasil analisa grading mangga apel menggunakan fuzzy inference system diketahui bahwa algoritma fuzzy yang dihasilkan memiliki akurasi tertinggi 0.773 atau $77 \%$ untuk mangga kondisi 1. Pada mangga kondisi 2 dan 3 memiliki nilai akurasi yang sama yaitu 0.727 atau $72 \%$.Untuk hasil akurasi fuzzy mangga kondisi 2 sama dengan 3 namun sebenarnya outputfuzzy-nya berbeda. Perbedaan dari hasil output tiap kondisi hanya selisih beberapa desimal saja, sehingga jika di kategorikan terhadap grade-nya serta dihitung akurasinya maka yang terlihat adalah sama nilainya. Untuk mangga dengan kondisi 4 akurasinya 0.682 atau $68 \%$.

Digunakanlah decision tree sebagai metode pembanding dengan sistem FIS Mamdani yang telah diusulkan untuk mengetahui sebarapa bagus hasil akurasinya. Terlihat bahwa pada Gambar 9 nilai akurasi fuzzy setiap kondisi pengujian 
selalu lebih tinggi dibandingakan dengan hasil dari decision tree. Setiap kondisi pengujian pada decision tree juga semakin menurun nilai akurasinya sebanding dengan penambahan motion blur.

PadaGambar grafik 9 juga dapat diketahui bahwa nilai akurasinya semakin menurun. Penurunan akurasi pada sistemgrading mangga ini disebabkan karena citra mengalami deraumotionblur yang berlebih, yang ditunjukkan dengan penambahan nilai pada parameter len dan theta. Nilai len menyatakan seberapa cepat citra tersebut mengalami motion blur, sedangkan theta menyatakan derajat terhadap arah blur.

\section{Kesimpulan}

Dari hasil evaluasi diperoleh akurasi tertinggi yaitu $77 \%$ untuk grading pada mangga kondisi 1.Untuk mangga yang mengalami deraumotionblur hasil akurasinya cenderung turun, hal ini dikarena nilai fitur-fiturnya juga turun akibat dari kurang efektifnya bagian preprocessing. Semakin citra mangga tersebut mengalami derau motionblur atau dalam kondisi nyata pergerakan dari conveyer belt semakin cepat maka proses grading-nya tidak begitu bagus.Dilakukan segementasi dengan Otsu thresholding untuk mendapatkan ROI. Namun ada beberapa citra yang hasil segmentasinya tidak begitu bagus, akibatnya beberapa bagian dari citra ada yang hilang. Dengan hilangnya beberapa bagian citra tersebut menyebabkan rotasi dari ROI yang kurang tepat sehingga hasil ektraksi fiturnya kurang begitu mendukung untuk grading.

\section{Saran}

Saran untuk tahapan pengembangan selanjutnya perlu dilakukan perbaikan dan penambahan fitur supaya hasilnya lebih akurat namun perlu diperhitungkan seberapa cepat sistem dapat melakukan grading karena nantinya bisa diterapkan secara realtime. Selain itu perlu dilakukan proses tambahan pada bagian preprocessing dibagian segmentasi seperti pembentukan kembali bagian dari ROI mangga yang hilang.

\section{Daftar Pustaka}

[1] J. Brezmes, M. L. L. Fructuoso, E. Llobet, X. Vilanova, I. Recasens, J. Orts, et al., "Evaluation of an Electronic Nose to Assess Fruit Ripeness," Sensors Journal IEEE, vol. 5, pp. 97 - 108, 2005.

[2] C. M. Christensen, Journal of Food Science, vol. 48, pp. 787-790, 1983.

[3] A. R. Mansor, M. Othman, M. N. A. Bakar, K. A. Ahmad, and T. R. Razak, "Fuzzy Ripening Mango Index Using RGB Colour Sensor Model," Journal of Arts, Science \& Commerce, vol. 5, 2014.

[4] H. Zheng and H. Lu, "A Least-Squares Support Vector Machine (LS-SVM) Based on Fractal Analysis and CIELab Parameters for The Detection of Browning Degree on Mango," Computers and Electronics in Agriculture, vol. 83, pp. 47-51, 2012.

[5] D. Savakar, "Identification and Classification of Bulk Fruits Images using Artificial Neural Networks," International Journal of Engineering and Innovative Technology (IJEIT), vol. 1, pp. 36-40, 2012.

[6] A. M. Vyas, B. Talati, and S. Naik, "Quality Inspection and Classification of Mangoes using Color and Size Features," International Journal of Computer Applications, vol. 98, pp. 15, 2014.

[7] C. S. Nandi, B. Tudu, and C. Koley, "A Machine Vision-Based Maturity Prediction System for Sorting of Harvested Mangoes," IEEE Transactions on Instrumentation and Measurement, vol. 63, pp. 1722 1730, 31 January 20142014.

[8] C. S. Nandi, B. Tudu, and C. Koley, "Machine Vision Based Automatic 
Fruit Grading System using Fuzzy Algorithm," presented at the International Conference on Control, Instumentation, Energy \& Communication (CIEC), 2014.

[9] D. Putra, Pengolahan Citra Digital. Yogyakarta: Andi Offset, 2010.

[10] R. C. Gonzalez and R. E. Woods. (2002). Digital Image Processing (Second Edition ed.).

[11] K. Sri, Aplikasi Logika Fuzzy Yogyakarta: Graha Ilmu, 2010. 